\title{
Intake, digestibility, and performance of steers fed diets based on two corn silage hybrids and two concentrate levels
}

\author{
[Consumo, digestibilidade e desempenho de novilhos alimentados com dietas a base de silagem de dois \\ híbridos de milho e dois níveis de concentrado] \\ F.H.M. Chizzotti ${ }^{1}$, O.G. Pereira ${ }^{2}$, S.C. Valadares Filho ${ }^{2}$, L.O. Tedeschi ${ }^{3}$, \\ K.G. Ribeiro ${ }^{4}$, D.H. Pereira \\ ${ }^{1}$ Universidade Federal de Lavras - Lavras, MG \\ ${ }^{2}$ Universidade Federal de Viçosa - Viçosa, MG \\ ${ }^{3}$ Texas A\&M University - College Station, Texas, USA \\ ${ }^{4}$ Universidade Federal dos Vales do Jetiquitinhonha e Mucuri - Diamantina, MG \\ ${ }^{5}$ Universidade Federal do Mato Grosso - Sinop, MT
}

\begin{abstract}
A trial involving a $2 \times 2$ factorial arrangement of treatments was conducted to evaluate two corn silage hybrids (Agromen, AGN35-A42) and (Bayer, A3663) and concentrate levels (25 and 50\%) on animal performance. Twenty-four Holstein x Zebu crossbred steers, averaging $335 \pm 30 \mathrm{~kg}$ of $\mathrm{BW}$, were distributed in six randomized blocks to evaluate intake, digestibility, and performance. Treatments consisted of $75 \%$ corn silage A $+25 \%$ concentrate, $50 \%$ corn silage A $+50 \%$ concentrate, $75 \%$ corn silage B $+25 \%$ concentrate, and $50 \%$ corn silage $\mathrm{B}+50 \%$ concentrate (dry matter basis); formulated to be isonitrogenous (13\% crude protein, dry matter basis). There were no differences in the daily intakes of dry matter (DM), organic matter (OM), and crude protein. Additionally, there was a concentrate effect on non-fiber carbohydrates and total digestible nutrients intakes, and on total apparent digestibility of DM and OM, with higher intakes for steers fed diets with $50 \%$ of concentrate. However, average daily gain (ADG) was not influenced by treatments. The utilization of both corn silage hybrids in association with $25 \%$ of concentrate is a good option to feed crossbred steers with ADG close to $1.0 \mathrm{~kg}$ in order to reduce diet cost.
\end{abstract}

Keywords: steer, feedlot, roughage, total digestible nutrient

\section{RESUMO}

Avaliaram-se, em esquema factorial 2x2, o efeito das silagens de dois híbridos de milho (A: Agromen AGN35-A42; B:Bayer - A3663) e dois níveis de concentrado (25 e 50\%) sobre o desempenho animal. Para avaliar o consumo, a digestibilidade e o desempenho animal, utilizaram-se 24 novilhos cruzados, Holandês x Zebu, com média de peso de $335 \pm 30 \mathrm{~kg}$, distribuídos em seis blocos ao acaso. Os tratamentos consistiram em $75 \%$ de silagem de milho $A+25 \%$ de concentrado; $50 \%$ de silagem de milho $A+50 \%$ de concentrado; $75 \%$ de silagem de milho $B+25 \%$ de concentrado; e $50 \%$ de silagem de milho $B+50 \%$ de concentrado (na base de matéria seca) e foram formulados para serem isonitrogenados (13\% proteína bruta). Não houve diferenças entre os consumos diários de matéria seca, matéria orgânica e proteína bruta. Houve efeito de concentrado sobre os consumos de carboidratos não-fibrosos e nutrientes digestíveis totais, e sobre as digestibilidades da matéria seca e da matéria orgânica. O maior consumo foi observado em animais alimentados com dietas que continham 50\% de concentrado. Entretanto, o ganho de peso diário não foi influenciado pelos tratamentos. A utilização de silagem dos dois híbridos de milho associada a $25 \%$ de concentrado é uma alternativa para reduzir o custo de dietas para novilhos em confinamento, com ganho de peso diário próximo a $1 \mathrm{~kg}$.

Palavras-chave: novilho, confinamento, volumoso, nutriente digestivel total

Recebido em 18 de junho de 2009

Aceito em 12 de julho de 2010

E-mail: fernandachizzotti@yahoo.com.br 


\section{INTRODUCTION}

The feeding is the most expensive component of feedlot systems, mainly the concentrate ration cost. Thus, interactions and impacts of use of different forage and concentrate ratios are extremely important to analyze the optimal relationship between cost and animal performance. Many studies have showed contradictory results about concentrate levels in beef cattle diets (Moraes et al., 2002; Costa et al., 2005; Pereira et al., 2006), so researches regarding concentrate ratio is yet necessary. In addition, the quality of silage is also fundamental to get good economic results, because of using good quality silage, the utilization of concentrate can be decreased and, consequently, the diet cost will be lower.

Whole-plant corn silage is a popular forage source for ruminants due to its high yielding properties, energy content, relatively high palatability, and incorporating easily into total mixed ration (Gomes, 2002). Furthermore, corn has high water soluble carbohydrate content, adequate lactic acid production and, consequently, results in good quality silage.

However, hybrid, maturity, and moisture content are some of the factors that can alter the nutritive value of corn silage (Johnson et al., 2002). Several studies have shown differences between hybrids in nutrient composition of whole plant and yield of dry matter (DM) of corn (Hunt et al., 1993; Xu et al., 1995; Melo et al., 1999; Oliveira et al., 2003; Qiu et al., 2003). Commercial corn hybrids that are to be harvested for silage have been selected on the basis of agronomic traits such as grain yield and disease resistance (Bal et al., 2000; Clark et al., 2002) and differences in the nutritive value of whole-plant corn silages related to corn genetics have been ignored (Bal et al., 2000). Therefore, the choice of hybrid for silage should include agronomic traits, evaluation of nutritive value, as well as the performance of animals fed those silages.

The commercial corn hybrids AGN35-A42 (Agromen) and A3663 (Bayer) are indicated for both corn grain and whole-plant corn silage, although feeding trials involving these corn silage hybrids, at the same environment condition, to evaluate animal performance are limited. The objective of this study was to determine the effects of two corn silage hybrids and two concentrate levels on intake, digestibility, and animal performance in crossbred steers.

\section{MATERIAL AND METHODS}

Two corn hybrids, (Agromen, AGN35-A42 and Bayer, A3663) were used in this trial. Agromen (AGN35-A42) is a double cross hybrid and has an ultra-short-season life cycle while Bayer (A3663) is a three-way cross hybrid with a shortseason life cycle. Both corn hybrids are indicated to production of grains and whole-plant silage. Diets were formulated to be isonitrogenous (13\% crude protein - CP, DM basis). Treatments were arranged in a $2 \times 2$ arrangement and included main effects of corn silage hybrids (Agromen, AGN35-A42 and Bayer, A3663) and concentrate levels (25 and 50\%). Treatments consisted of $75 \%$ of corn silage A $+25 \%$ of concentrate (A25), $50 \%$ of corn silage $\mathrm{A}+50 \%$ of concentrate (A50), $75 \%$ of corn silage B $+25 \%$ of concentrate (B25), and $50 \%$ of corn silage B + $50 \%$ (B50); on DM basis (Table 2).

Both corn hybrids, Agromen (AGN35-A42) and Bayer (A 3663), were sowed on November 2003 and approximately $52 \mathrm{~kg} \mathrm{~N} \mathrm{ha}^{-1} ; 183 \mathrm{~kg} \mathrm{P}_{2} \mathrm{O}_{5} \mathrm{ha}^{-1}$; and $105 \mathrm{~kg} \mathrm{~K}_{2} \mathrm{O}$ ha $^{-1}$ were applied as start up fertilizer. Thirty days later, $112 \mathrm{~kg} \mathrm{~N} \mathrm{ha}^{-1} ; 26 \mathrm{~kg}$ $\mathrm{P}_{2} \mathrm{O}_{5} \mathrm{ha}^{-1}$; and $112 \mathrm{~kg} \mathrm{~K}_{2} \mathrm{O}$ ha $^{-1}$ were applied. Corn hybrids were harvested at 100 days after the sowing, when the milkline was between $1 / 3$ and $2 / 3$ of the grain, and ensiled without additives in a horizontal-type silo, with approximately 50tons capacity.

Twenty-four Holstein x Zebu crossbred steers, averaging $335 \pm 30 \mathrm{~kg}$ body weight $(\mathrm{BW})$, were distributed in six randomized blocks to evaluate intake and digestibility of nutrients, and their performance in the feedlot. Steers were blocked into six groups based on initial BW and randomly allotted to one of four treatments (six steers per treatment). The animals were treated for internal and external parasites at the beginning of the experiment and kept in individual pens of approximately $10 \mathrm{~m}^{2}$, with protected feeders and waterier. The trial was conducted for $99 \mathrm{~d}$ ( $15 \mathrm{~d}$ for diet adaptation and three periods of $28 \mathrm{~d}$ for data collection). 
Steers were individually fed ad libitum twice daily at 07:00 and 15:00 h. Diets were fed as total mixed ration in which corn silage and concentrate (previously mixed) were weighted and mixed during the feeding. Orts were collected and weighed once daily and diets were daily adjusted to yield orts of about 5 to $10 \%$ of offered. Animals had free access to water at all times. Feed ingredients and orts were daily sampled and composited by weight and period.

For each animal, the DM intake (DMI) was daily measured and grab samples of feces (around $200 \mathrm{~g}$ ) were collected from day 14 to 16 of the second period with collecting intervals of $28 \mathrm{~h}$. Indigestible acid detergent fiber (iADF) was used as an internal marker to estimate apparent nutrient digestibility and fecal output.

The average daily gain (ADG) was calculated as the difference between the final and initial shrunk BW (SBW) (16h of fasting) divided by the number of days of feeding (84d). Gain efficiency was calculated as ADG divided by DMI.

The composite sample for each material (silage, concentrate, orts, and feces) was used to determine the DM (method \#934.01; Official..., 1990); organic matter (OM) determined by ash (method \#924.05; Official..., 1990); CP obtained by total $\mathrm{N}$ determination using the micro Kjeldahl technique (method \#920.87; Official..., 1990) and a fixed conversion factor (6.25); ether extract (EE) gravimetrically determined after extraction using petroleum ether in a Soxhlet instrument (method \#920.85; Official..., 1990); neutral detergent fiber (NDF) (Van Soest et al., 1991); acid detergent fiber (ADF) (method \#973.18; Official..., 1990); and sulfuric acid lignin (Van Soest et al., 1991). The NDF and non-fiber carbohydrates (NFC) were not corrected for ash or protein. The iADF (ADF remaining after a $144 \mathrm{~h}$ in situ incubation in a rumen-cannulated cow) was determined according to Cochran et al. (1986) and the digestibility of nutrients was calculated as shown in Equation 1:
Nutrient digestibility $=100 \times[100-(\%$ of iADF of the feed $/ \%$ of iADF of the feces $) \times(\%$ of nutrient of the feces $/ \%$ of nutrient of the feed)]

NFC were calculated by difference as shown in Equation 2:

$\mathrm{NFC}=100-(\% \mathrm{CP}+\% \mathrm{NDF}+\% \mathrm{EE}+\%$ ash $)$

Apparent total digestible nutrient (TDN) was calculated as shown in Equation 3 (Nutrient..., 2001):

App $\mathrm{TDN}=$ [digestible $\mathrm{CP}+$ digestible $\mathrm{NDF}+$ digestible NFC + $(2.25 \times$ digestible EE $)] /$ DMI.

All data were analyzed as a randomized complete block design with a $2 \times 2$ factorial arrangement of treatments using the GLM procedure of SAS (Statistical analyses system Inst. Inc., Cary, NC). Treatment differences were considered to be significant when $\mathrm{P} \leq 0.05$.

\section{RESULTS}

Chemical composition of silages is presented in Table 1. Both corn silage hybrids had similar values of nutrients, except for DM and NFC, which were numerically lower in corn silage hybrid A than those observed in corn silage hybrid $\mathrm{B}$. In addition, the corn silage $\mathrm{A}$ had $\mathrm{pH}$ value 3.6 and $\mathrm{N}-\mathrm{NH}_{3} /$ Total $\mathrm{N} 8.4 \%$, while corn silage $\mathrm{B}$ had $\mathrm{pH} 3.5$ and $\mathrm{N}-\mathrm{NH}_{3} /$ Total $\mathrm{N} 6.3 \%$.

The nutrient composition of the diets is shown in Table 2. As expected, diets with $50 \%$ of concentrate provided higher amounts of DM, NFC, and TDN than those diets with $25 \%$ of concentrate.

Table 3 shows the mean intake of nutrients. The intake of DM, OM, and CP were not affected by treatments $(\mathrm{P}>0.05)$. On the other hand, concentrate levels had a positive effect $(\mathrm{P}<0.05)$ on the intakes of NFC and TDN, which were higher in diets with $50 \%$ of concentrate than those with $25 \%$. The intake of NDF also was influenced by concentrate levels $(\mathrm{P}<0.0001)$ which were lower in steers fed diets with $50 \%$ of concentrate. There was an effect $(\mathrm{P}<0.001)$ of silage on EE intake. 
Intake, digestibility, and performance...

Table 1. Chemical composition of corn silages

\begin{tabular}{|c|c|c|}
\hline Item & Corn silage $\mathrm{A}$ & Corn silage B \\
\hline DM, $\%$ & 28.01 & 32.45 \\
\hline $\mathrm{OM}, \% \mathrm{DM}$ & 96.12 & 96.02 \\
\hline $\mathrm{CP}, \% \mathrm{DM}$ & 7.00 & 6.02 \\
\hline $\mathrm{NDF}, \% \mathrm{DM}$ & 53.00 & 51.14 \\
\hline iADF, \%DM & 12.50 & 11.80 \\
\hline EE, \%DM & 2.25 & 2.02 \\
\hline NFC, \%DM & 33.87 & 36.86 \\
\hline Lignin, \%DM & 3.62 & 3.45 \\
\hline $\mathrm{pH}$ & 3.60 & 3.50 \\
\hline $\mathrm{NH}_{3}-\mathrm{N}, \%$ of total $\mathrm{N}$ & 8.40 & 6.30 \\
\hline
\end{tabular}

$\mathrm{DM}=$ dry matter; $\mathrm{OM}=$ organic matter; $\mathrm{CP}=$ crude protein; $\mathrm{NDF}=$ neutral detergent fiber; $\mathrm{iADF}=$ indigestible $\mathrm{ADF} ; \mathrm{EE}=$ ether extract; and NFC $=$ non-fiber carbohydrates.

Table 2. Ration composition and analyzed content of diets

\begin{tabular}{lcccc}
\hline \multirow{2}{*}{ Item } & \multicolumn{2}{c}{ Corn silage A } & \multicolumn{2}{c}{ Corn silage B } \\
\cline { 2 - 5 } & 25 & 50 & 25 & 50 \\
\hline Corn silage & 75.0 & 50.0 & 75.0 & 50.0 \\
Ground corn & 14.86 & 41.0 & 14.86 & 41.0 \\
Cottonseed meal & 8.27 & 7.03 & 8.27 & 7.03 \\
Urea & 1.00 & 1.00 & 1.00 & 1.00 \\
Ammonium sulfate & 0.10 & 0.10 & 0.10 & 0.10 \\
Sodium chloride & 0.25 & 0.25 & 0.25 & 0.25 \\
Calcite limestone & 0.50 & 0.60 & 0.50 & 0.02 \\
Mineral premix ${ }^{1}$ & 0.02 & 0.02 & 0.02 & 61.60 \\
& & Nutrient content of diets & 94.39 \\
DM, \% & 43.53 & 59.38 & 46.91 & 12.64 \\
OM, \%DM & 94.28 & 94.44 & 94.20 & 31.80 \\
CP, \%DM & 13.06 & 13.13 & 12.32 & 7.10 \\
NDF, \%DM & 43.74 & 32.73 & 42.35 & 2.02 \\
iADF, \%DM & 10.58 & 7.45 & 10.06 & 51.95 \\
EE, \%DM & 2.14 & 2.15 & 1.95 & 2.37 \\
NFC, \%DM & 38.81 & 50.46 & 41.04 & 3.03 \\
Lignin, \%DM & 3.16 & 2.46 & \\
\hline${ }^{1}$ Composition (\%): cooper sulfate (22.50), cobalt sulfate (1.40), zinc sulfate (75.40), potassium iodate (0.50), and sodium \\
selenite (0.20). \\
${ }^{2}$ DM = dry matter; OM = organic matter; CP = crude protein; NDF = neutral detergent fiber; iADF = indigestible ADF; EE \\
= ether extract; and NFC = non-fiber carbohydrates.
\end{tabular}

Table 3. Nutrients intake and animal performance according to different silage hybrids and concentrate levels

\begin{tabular}{|c|c|c|c|c|c|c|c|c|}
\hline \multirow{2}{*}{ Item } & \multicolumn{2}{|c|}{ Corn silage A } & \multicolumn{2}{|c|}{ Corn silage B } & \multirow{2}{*}{ SEM } & \multicolumn{3}{|c|}{$\mathrm{P}$-value } \\
\hline & 25 & 50 & 25 & 50 & & Silage & Conc & $\mathrm{S} \times \mathrm{C}$ \\
\hline \multicolumn{9}{|c|}{ Intake, $\mathrm{kg} / \mathrm{d}$} \\
\hline DM & 8.84 & 9.00 & 8.57 & 9.01 & 0.29 & 0.67 & 0.33 & 0.65 \\
\hline $\mathrm{OM}$ & 8.50 & 8.70 & 8.26 & 8.72 & 0.28 & 0.69 & 0.26 & 0.66 \\
\hline $\mathrm{CP}$ & 1.18 & 1.15 & 1.11 & 1.10 & 0.04 & 0.16 & 0.61 & 0.83 \\
\hline EE & 0.20 & 0.20 & 0.18 & 0.19 & 0.006 & 0.02 & 0.15 & 0.42 \\
\hline NDF & 3.56 & 2.60 & 3.58 & 2.66 & 0.12 & 0.81 & $<0.0001$ & 0.83 \\
\hline NFC & 3.60 & 4.83 & 3.61 & 4.94 & 0.14 & 0.64 & $<0.0001$ & 0.70 \\
\hline TDN & 5.78 & 6.32 & 5.60 & 6.14 & 0.17 & 0.32 & 0.006 & 0.99 \\
\hline \multicolumn{9}{|c|}{ Intake, \%BW } \\
\hline DM & 2.32 & 2.37 & 2.30 & 2.37 & 0.06 & 0.81 & 0.34 & 0.90 \\
\hline $\mathrm{NDF}$ & 0.93 & 0.69 & 0.96 & 0.70 & 0.03 & 0.52 & $<0.0001$ & 0.90 \\
\hline \multicolumn{9}{|c|}{ Animal performance } \\
\hline ADG & 1.07 & 1.13 & 1.06 & 1.14 & 0.07 & 0.96 & 0.39 & 0.92 \\
\hline FE & 8.31 & 8.09 & 8.19 & 7.92 & 0.42 & 0.73 & 0.57 & 0.95 \\
\hline
\end{tabular}

$\mathrm{DM}=$ dry matter, $\mathrm{OM}=$ organic matter, $\mathrm{CP}=$ crude protein, $\mathrm{EE}=$ ether extract, $\mathrm{NDF}=$ neutral detergent fiber, $\mathrm{NFC}=$ nonfiber carbohydrates, TDN $=$ total digestible nutrient, $\mathrm{ADG}=$ average daily gain, and $\mathrm{FE}=$ feed efficiency.

$\mathrm{S} \times \mathrm{C}=$ silage and concentrate interaction effect. 
ADG and feed efficiency (FE) were not affected $(\mathrm{P}>0.05)$ by treatments (Table 3$)$.

The digestibility of nutrients is shown in Table 4. Total tract apparent digestibility of DM and OM were affected by concentrate levels $(\mathrm{P}<0.05)$, with higher values to diets with $50 \%$ of concentrate than those with $25 \%$. The TDN percentage of the diets was also influenced by concentrate levels $(\mathrm{P}<0.05)$, which, as expected, was higher to diets with $50 \%$ of concentrate than diets with $25 \%$.

Table 4. Apparent total tract digestibility of nutrients and \% TDN of the diets according to different silage hybrids and concentrate levels

\begin{tabular}{lcccccccc} 
& \multicolumn{2}{c}{ Corn silage A } & \multicolumn{2}{c}{ Corn silage B } & \multicolumn{3}{c}{ P-value } \\
\cline { 2 - 9 } Item & 25 & 50 & 25 & 50 & SEM & Silage & Concentrate & SxC \\
\hline DM, \% & 65.26 & 69.43 & 63.25 & 66.42 & 1.38 & 0.09 & 0.02 & 0.72 \\
OM, \% & 66.06 & 70.30 & 64.57 & 68.15 & 1.32 & 0.19 & 0.01 & 0.80 \\
CP, \% & 65.22 & 64.93 & 63.04 & 65.73 & 0.87 & 0.43 & 0.18 & 0.11 \\
EE, \% & 82.15 & 84.37 & 81.48 & 84.46 & 1.59 & 0.86 & 0.12 & 0.81 \\
NDF, \% & 48.31 & 46.44 & 49.08 & 41.24 & 2.61 & 0.41 & 0.08 & 0.27 \\
NFC, \% & 81.58 & 83.17 & 78.70 & 79.96 & 1.66 & 0.09 & 0.40 & 0.92 \\
TDN, \% & 65.47 & 70.65 & 65.46 & 68.19 & 1.40 & 0.39 & 0.01 & 0.40 \\
\hline
\end{tabular}

$\mathrm{DM}=$ dry matter, $\mathrm{OM}=$ organic matter, $\mathrm{CP}=$ crude protein, $\mathrm{EE}=$ ether extract, $\mathrm{NDF}=$ neutral detergent fiber, $\mathrm{NFC}=$ non-fiber carbohydrates, and TDN $=$ total digestible nutrient.

$\mathrm{S} \times \mathrm{C}=$ silage and concentrate interaction effect.

\section{DISCUSSION}

Overall, both silages had similar contents of nutrients, except for \% of DM, NDF, and NFC (Table 1). Silage A had about $4 \%$ less DM, $2 \%$ more NDF, and 3\% less NFC than silage B. These characteristics probably are related with characteristics of each corn hybrid, since both hybrids got the same fertilization and were harvested at the same occasion. However, these numeric differences did not affect the intake of nutrients and performance of animals. Freitas et al. (2003) also observed no effect of silages of five corn genotypes on DM intake and digestibility. According to Muck and Pitt (1993), both silages had good quality due to their adequate percentage of $\mathrm{N}-\mathrm{NH}_{3} /$ Total $\mathrm{N}$ and $\mathrm{pH}$ values.

The diets with $50 \%$ of concentrate in association with either corn silage hybrids provided higher amounts of DM, NFC, and TDN and NDF lower than $25 \%$ concentrate diets, certainly due to higher percentage of corn ground in those diets.

The effect of treatments on intake of nutrients was similar in both experiments, except the EE intake that was affected by silage hybrid.

Although some authors have found linear (Dias et al., 2000; Souza et al., 2002; Pereira et al.,
2006) or quadratic (Verás et al., 2000; Itavo et al., 2002; Costa et al., 2005; Silva et al., 2005) increases in DM intake with increase of concentrate levels in beef cattle diets, no effects of treatments were observed in this study. Moraes et al. (2002) also found no increases in DM intake with the concentrate levels. Probably, these variations among studies occurred due to other variables related to kind and age of animal, climatic conditions, and days on feeding that can affect the DM intake.

The higher intake of NFC and TDN and lower intake of NDF in steers fed diets with $50 \%$ of concentrate likely occurred as a result of higher amounts of ground corn in these diets than those with $25 \%$. Similar results were found by Costa et al. (2005) who evaluated the effects of levels of concentrate $(5,35$, and $65 \%, \mathrm{DM})$ on intake of nutrients in Nellore steers. The higher EE intake observed in diets with corn silage hybrid A probably was due to slightly higher amount of $\mathrm{EE}$ in this silage (Table 1).

The lack of effect of treatments on ADG and feed efficiency was no expected. Increases in ADG are expected when animals are fed high energy diets. In these two studies, 50\% concentrate diets had more TDN content than those diets with $25 \%$. It is possible that animal 
breed might have limited the gain. Also, when animals are fed with more energy diets, their maintenance energy requirements increase too (i.e. the internal organs increase their sizes), what can be limited the gain and feed efficiency. Pereira et al. (2006) found no differences in ADG and feed efficiency when fed crossbred steers with sorghum silage and levels of concentrate $(20,35,50$, and $65 \%, \mathrm{DM})$. On the other hand, Resende et al. (2001), Vargas Jr. et al. (2002), and Costa et al. (2005) observed increases in the ADG when concentrate levels were augmented in the diets.

The increases observed in DM and OM digestibilities in diets with $50 \%$ of concentrate likely occurred due to higher amount of nonfiber carbohydrates in those diets than in $25 \%$ concentrate diets. In general, the apparent digestibility of NFC is higher than digestibility of structural carbohydrates, so the replacement of corn silage by corn ground in $50 \%$ concentrate diets provided more NFC to those diets than in $25 \%$ concentrate diets. Similar results were observed by Cardoso et al. (2000), Ítavo et al. (2002), and Putrino et al. (2007).

There was no effect $(\mathrm{P}=0.08$, Table 4) of concentrate on NDF digestibility. Is expected that diets with more concentrate provide more amylolytic microbes, what can negatively affect the fiber digestion. However, this effect did not occurred in this study, maybe due to the small range between the two levels of concentrate evaluated (25 and 50\%), what probably was not enough to detect this effect. Pereira et al. (2006) and Putrino et al. (2007) observed linear effect of concentrate levels on NDF digestibility, but both evaluated greater ranges of concentrate levels (20 up to $65 \%$, and 20 up to $80 \%$; respectively).

\section{CONCLUSIONS}

The utilization of either corn silage hybrids evaluated in association with $25 \%$ of concentrate is a good option to feed crossbred steers (Holstein $x$ Zebu) with ADG close to $1.0 \mathrm{~kg}$, what might reduce diet cost. The findings of the present study suggest that, as the two corn silage hybrids evaluated had similar behavior on animal performance, despite of concentrate level, the choice for the more adequate corn silage hybrid should include the agronomic traits.

\section{REFERENCES}

BAL, M.A.; SHAVER, R.D.; JIROVEC, A.G. et al. Crop processing and chop length of corn silage: effects on intake, digestion, and milk production by dairy cows. J. Dairy Sci., v.83, p.1264-1273, 2000.

CARDOSO, R.C.; VALADARES FILHO, S.C.; COELHO DA SILVA, J.F. et al. Consumo e digestibilidades aparentes totais e parciais de rações contendo diferentes níveis de concentrado, em novilhos F1 Limousin x Nelore. Rev. Bras. Zootec., V.29, p.1832-1841, 2000.

CLARK, P.W.; KELM, S.; ENDERS, M.I. Effect of feeding a corn hybrid selected for leafiness as silage or grain to lactating dairy cattle. J. Dairy Sci., v.85, p.607-612, 2002.

COCHRAN, R.C.; ADAMS, D.C.; WALLACE, J.D. et al. Predicting digestibility of different diets with internal markers: evaluation of four potential markers. J. Anim. Sci., v.63, p.1476-1483, 1986.

COSTA, M.A.L.; VALADARES FILHO. S.C.; PAULINO, M.F. et al. Desempenho, digestibilidade e características de carcaça de novilhos zebuínos alimentados com dietas contendo diferentes níveis de concentrado. Rev. Bras. Zootec., v.34, p.268-279, 2005.

DIAS, H.L.C.; VALADARES FILHO, S.C.; COELHO DA SILVA, J.F. et al. Consumo e digestões totais e parciais em novilhos F1 Limousin $\mathrm{x}$ Nelore alimentados com dietas com cinco níveis de concentrado. Rev. Bras. Zootec., v.29, p.545-554, 2000.

FREITAS, G.A.R.; COELHO, S.G.; GONÇALVES, L.C. Consumo e digestibilidade aparente da matéria seca, proteína e energia bruta, e balanço de nitrogênio das silagens de cinco genótipos de milho. Arq. Bras. Med. Vet. Zootec., v.55, p.443-449, 2003.

GOMES, S.T. Situação atual e tendências da competitividade de sistemas de produção. In: VILELA, D. et al. (Eds.) $O$ agronegócio do leite e políticas públicas para o seu desenvolvimento sustentável. Juiz de Fora: Embrapa Gado de Leite, 2002. p.67-81.

HUNT, C.W.; KEZAR, W.D.; HINMAN, D. et al. Effects of hybrid and ensiling with and without a microbial inoculant on the nutritional characteristics of whole-plant corn. J. Anim. Sci., 71, 38-43, 1993.

ÍTAVO, L.C.V.; VALADARES FILHO, S.C.; SILVA, F.F. et al. Consumo e digestibilidade aparentes totais e parciais de nutrientes em novilhos alimentados com dietas contendo vários níveis de concentrado. Rev. Bras. Zootec., v.31, p.1543-1552, 2002. 
JOHNSON, L.M.; HARRISON, J.H.; DAVIDSON, D. et al. Corn silage management I: effects of hybrid, maturity, and mechanical processing on chemical and physical characteristics. J. Dairy Sci., v.85, p.833-853, 2002.

MELO, W.M.C.; PINHO, R.G.V.; CARVALHO, M.L.M. et al. Avaliação de cultivares de milho para a produção de silagem na região de Lavras-MG. Cienc. Agrotec., v.23, p.31-39, 1999.

MORAES, S.A.; PEREIRA, O.G.; GARCIA, R. et al. Consumo e digestibilidade aparente de nutrientes, em bovinos recebendo dietas contendo silagem de milho e concentrado em diferentes proporções. In: REUNIÃO ANUAL DA SOCIEDADE BRASILEIRA DE ZOOTECNIA, 39., 2002, Recife. Anais... Recife: SBZ, 2002.

MUCK, R.E.; PITT, R.E. Ensiling and its effect on crop quality silage. In: SILAGE PRODUCTION FROM SEED TO ANIMAL, 67., 1993, New York. Proceedings... New York: NRAES, 1993. p.57-66.

NUTRIENT requirements of dairy cattle. 7.ed. Washington, DC: National Academy, 2001. 381p.

OFFICIAL methods of analyses, 15.ed. Washington, DC: AOAC, 1990.

OLIVEIRA, J.S.; SOBRINHO, F.S.; PEREIRA, R.C. et al. Potencial de utilização de híbridos comerciais de milho para silagem na Região Sudeste do Brasil. Rev. Bras. Milho Sorgo., v.2, p.62-71, 2003.

PEREIRA, D.H.; PEREIRA, O.G.; VALADARES FILHO, S.C. et al. Consumo, digestibilidade dos nutrientes e desempenho de bovinos de corte recebendo silagem de sorgo (Sorghum bicolor (L.) Moench) e diferentes proporções de concentrado. Rev. Bras. Zootec., v.35, p.282-291, 2006.

PUTRINO, S.M.; LEME, P.R.; LUZ E SILVA, S. et al. Digestibilidade aparente de dietas com níveis crescentes de concentrado em novilhos Brangus e Nelore. Arq. Bras. Med. Vet. Zootec., v.59, p.406-413, 2007.

QIU, X.; EASTRIDGE, M.L.; WANG, Z. Effects of corn silage hybrid and dietary concentration of forage NDF on digestibility and performance by dairy cows. J. Dairy Sci., v.86, p.3667-3674, 2003.
RESENDE, F.D.; QUEIROZ, A.C.; OLIVEIRA, J.V. et al. Bovinos mestiços alimentados com diferentes proporções de volumoso:concentrado. 1. Digestibilidade aparente dos nutrientes, ganho de peso e conversão alimentar. Rev. Bras. Zootec., v.30, p.261269, 2001

SILVA, B.C.; PEREIRA, O.G.; PEREIRA, D.H. et al. Consumo e digestibilidade aparente total dos nutrientes e ganho de peso de bovinos de corte alimentados com silagem de Brachiaria brizantha e concentrado em diferentes proporções. Rev. Bras. Zootec., v.34, p.1060-1069, 2005.

SOUZA, V.G.; PEREIRA, O.G.; VALADARES FILHO, S.C. et al. Consumo e desempenho de bovinos de corte recebendo silagem de milho e concentrado em diferentes proporções. In: REUNIÃO ANUAL DA SOCIEDADE BRASILEIRA DE ZOOTECNIA, 39., 2002, Recife. Anais... Recife, 2002.

VAN SOEST, P.J.; ROBERTSON, J.B.; LEWIS, B.A. Methods for dietary fiber, neutral detergent fiber, and nonstarch polysaccharides in relation to animal nutrition. J. Dairy Sci., v.74, p.3583-3590, 1991.

VARGAS JR, F.M.; BONNECARRÈRE SANCHEZ, L.M.; PASCOAL, L.L. Desempenho de novilhos de corte alimentados com dietas contendo quantidades crescentes de concentrado associado à forragem de aveia (Avena strigosa) tratada com uréia. Arq. Bras. Med. Vet. Zootec., v.54, p.405-413, 2002.

VERÁS, A.S.C.; VALADARES FILHO, S.C.; COELHO DA SILVA, J.F. et al. Consumo de digestibilidade aparente em bovinos nelore, não castrados, alimentados com rações com diferentes níveis de concentrado. Rev. Bras. Zootec., v.29, p.2367-2378, 2000.

XU, S.; HARRISON, J.H.; KEZAR, W. et al. Evaluation of yield, quality, and plant composition of early-maturing corn hybrids harvested at three stages of maturity. Prof. Anim. Sci., v.11, p.157-165, 1995. 